Article

\title{
Impact of the Kunming-Bangkok Highway on Land Use Changes along the Route between Laos and Thailand
}

\author{
Fangyu Zheng ${ }^{1,2}$, Jiuming Huang ${ }^{3}$, Zhiming Feng ${ }^{1,2}$ and Chiwei Xiao ${ }^{1,2, *}$ \\ 1 Institute of Geographic Sciences and Natural Resources Research, Chinese Academy of Sciences, \\ Beijing 100101, China; zhengfy.19b@igsnrr.ac.cn (F.Z.); fengzm@igsnrr.ac.cn (Z.F.) \\ 2 University of Chinese Academy of Sciences, Beijing 100049, China \\ 3 State Key Laboratory of Earth Surface Processes and Resource Ecology, Faculty of Geographical Science, \\ Beijing Normal University, Beijing 100875, China; hjm@mail.bnu.edu.cn \\ * Correspondence: xiaocw@igsnrr.ac.cn
}

check for updates

Citation: Zheng, F.; Huang, J.; Feng,

Z.; Xiao, C. Impact of the

Kunming-Bangkok Highway on Land Use Changes along the Route between Laos and Thailand. Land 2021, 10, 991. https://doi.org/ 10.3390/land10090991

Academic Editor: Thomas W. Sanchez

Received: 26 July 2021

Accepted: 18 September 2021

Published: 19 September 2021

Publisher's Note: MDPI stays neutral with regard to jurisdictional claims in published maps and institutional affiliations.

Copyright: (c) 2021 by the authors. Licensee MDPI, Basel, Switzerland. This article is an open access article distributed under the terms and conditions of the Creative Commons Attribution (CC BY) license (https:/ / creativecommons.org/licenses/by/ $4.0 /)$.

\begin{abstract}
Road construction fragments the landscape, reduces connectivity, and drives land use changes. To our knowledge, little is known about the scope and intensity of the effects of cross-border roads on changes in land use. Here, with the land use data products provided by the US Agency for International Development's SERVIR Mekong project, using the GIS-based spatial analysis to quantitatively analyze and compare the effects of the cross-border road on land use changes within a $30 \mathrm{~km}$ buffer area along the Kunming-Bangkok Highway between Laos and Thailand. The results show the following: The greater the distance was from the highway, the smaller were the overall changes in land use within the buffer zone. A comparison of the situation before and after the road was opened in 2013 revealed significant differences in the most influential land use types of agricultural expansion, i.e., from $47.07 \%$ to $52.07 \%$ (the buffer zone was $1 \mathrm{~km}$ ). In particular, $57.32 \%$ (1381.93 ha) and $40.08 \%$ (966.46 ha) of the land occupied by forests had been converted into land for plantation and agriculture, respectively, from 2013 to 2018. The scope of the impact of the operational route on the dynamics of land use was inconsistent. The largest impact before the road became operational was within $4 \mathrm{~km}$ of the buffer zone $(0.26$ to 0.24$)$. Once the road had been opened, the range of its impact was beyond $10 \mathrm{~km}$ ( 0.63 to 0.57$)$. The work here can provide a scientific basis for regional transportation planning and the sustainable use of land resources.
\end{abstract}

Keywords: land use changes; comprehensive dynamic degree; expansion/reduction intensity index; Kunming-Bangkok Highway; SERVIR-Mekong

\section{Introduction}

Transport networks are continually expanding rapidly around the world and include cross-border roads. These transport routes have significantly improved the economy of cross-border dwellers and accessibility to such areas, but have also had undesirable local eco-environmental consequences. Access to the transportation infrastructure is a major driver of urbanization, along with factors such as proximity to urban land, demographics and economic growth, and policies for spatial expansion [1]. A new rapid transit system can stimulate, revitalize, order, optimize, and/or create infrastructure economies in the course of urban development [2]. In addition, urban sprawl, coupled with the demand for transportation infrastructures, potentially has direct and indirect effects on the environment, such as the destruction of landscapes (ecological corridors), habitats (e.g., plants and animals), and irreversible land use changes [3,4]. The construction of transportation infrastructures is based on land as a supporting force. Changes in it can enhance accessibility, and improvements to it can shape urban spatial expansion, restructure the country's land use patterns, and motivate the advancement of particular patterns [5]. While expressways have yielded significant benefits, they have also significantly affected the ecological environment [4]. The construction, operation, and maintenance of highways have changed 
the original landform as well as the form of land use. This has led to changes in the regional landscape pattern and the deterioration of the ecosystem through segmentation, interference, destruction, degradation, and pollution. Studies have shown that this impact extends to at least $15 \%$ to $20 \%$ of the world's landmass [6].

Various models and theories have been used to identify the effects of transportation on land use changes [7-9]. Ullman (1956), in his account of humanity's role in changing the face of the earth [10], claimed that "few forces have been more influential in modifying the Earth than transportation." Among them, the impact of rapid transport routes on land use is apparent mainly in the form of corridors at the microscopic scale, such as suburban functional areas in corridors along roads, in clusters or as corridor-cluster combinations [11]. Traffic systems and urban spatial structures influence each other [12]. Prevalent research on the connection between transportation and land use has focused on intercity corridors and paid little attention to the impact of transportation routes on temporal and spatial changes in various types of land use, particularly cross-border roads. Many impacts of this kind are evident, where ecological flows (natural processes) and patterns of biodiversity have been disrupted. Road networks crossing landscapes cause land erosion, and stream networks, valleys, and other landscapes are significantly interrupted [13]. Since landscapes and road systems are at the same scale, changes in the ecology of the landscape inexorably become important for planning transportation routes. Research has sought to understand the relation between roads and land use/land cover, along with its ecological and environmental effects [14-17]. The impact of roads on land use is constrained by the density of the road system and the conditions of the road itself, and in turn leads to spatial differences [18]. The above-mentioned effects are reflected in specific roads or sections of roads, and modeling this impact may be a complicated exercise. Therefore, it is difficult to reasonably determine the range of impact of the road on land use, where it is important to better understand the mechanism of the influence of roads on land use/land cover changes.

The road has a corridor effect, which means that newly constructed transport routes trigger quantitative and distributed adjustments in land in the relevant corridors. The corridor effect can be divided into the effects of exclusion and attraction, whereby adjustments closer to the transport route tend to be more intensive than those farther away from it $[19,20]$. Transportation plays a crucial role in shaping a region's spatial structure and influences accessibility to it [21]. Although past research has significantly enriched our knowledge of cross-border roads and land use changes, two relevant questions remain unanswered. First, how cross-border roads impact land use changes, in what type, extent, and degree? Second, how to quantitatively analyze the effects of cross-border roads on land use changes? The Kunming-Bangkok Highway is part of the Asian international highway network, and is a cooperative project by China, Laos, and Thailand. When completed, it had an important impact on the regional patterns of transportation and trade, but also gave rise to cross-border changes in land use. In this study, we use data from land use products from the US Agency for International Development's SERVIR Mekong project to characterize land use changes within a $30 \mathrm{~km}$ buffer of the Kunming-Bangkok Highway, and to assess the effects of cross-border roads on these changes.

\section{Materials and Methods}

\subsection{Study Areas}

The Kunming-Bangkok Highway is an important transportation artery connecting China to Southeast Asian countries by land(Figure 1). It is one of the key cooperative projects on infrastructure between China and the Association of Southeast Asian Nations, and the most important cross-border corridor (i.e., the north-south economic corridor) in the context of Greater Mekong Sub-Region Cooperation. This includes one of the four key highways connecting Yunnan Province in China to foreign countries through a bridgehead construction. The construction of the Kunming-Bangkok Highway started in 1992 in Kunming city of China. It enters Laos through the Mohan port of Xishuangbanna, passes through Chiang Khong in Thailand, the Huay Xai and Chiang Khong ports in Luang 
Namtha and Bokeo Provinces of Laos, respectively, and finally reaches the capital (i.e., Bangkok) of Thailand. The Kunming-Bangkok Highway generally has four lanes, and there are not too many restrictions. On the Laos Boding-Haikai Highway, there are many mountain roads in the Laos section of the highway, some of the roads are winding, and there are no guardrails on both sides of the road, and the passage of people and animals is relatively many. With a total length of $1807 \mathrm{~km}$, the Kunming-Bangkok Highway is divided into a Chinese section $(688 \mathrm{~km})$, a Laotian section $(229 \mathrm{~km})$, and a Thai section (890 km).

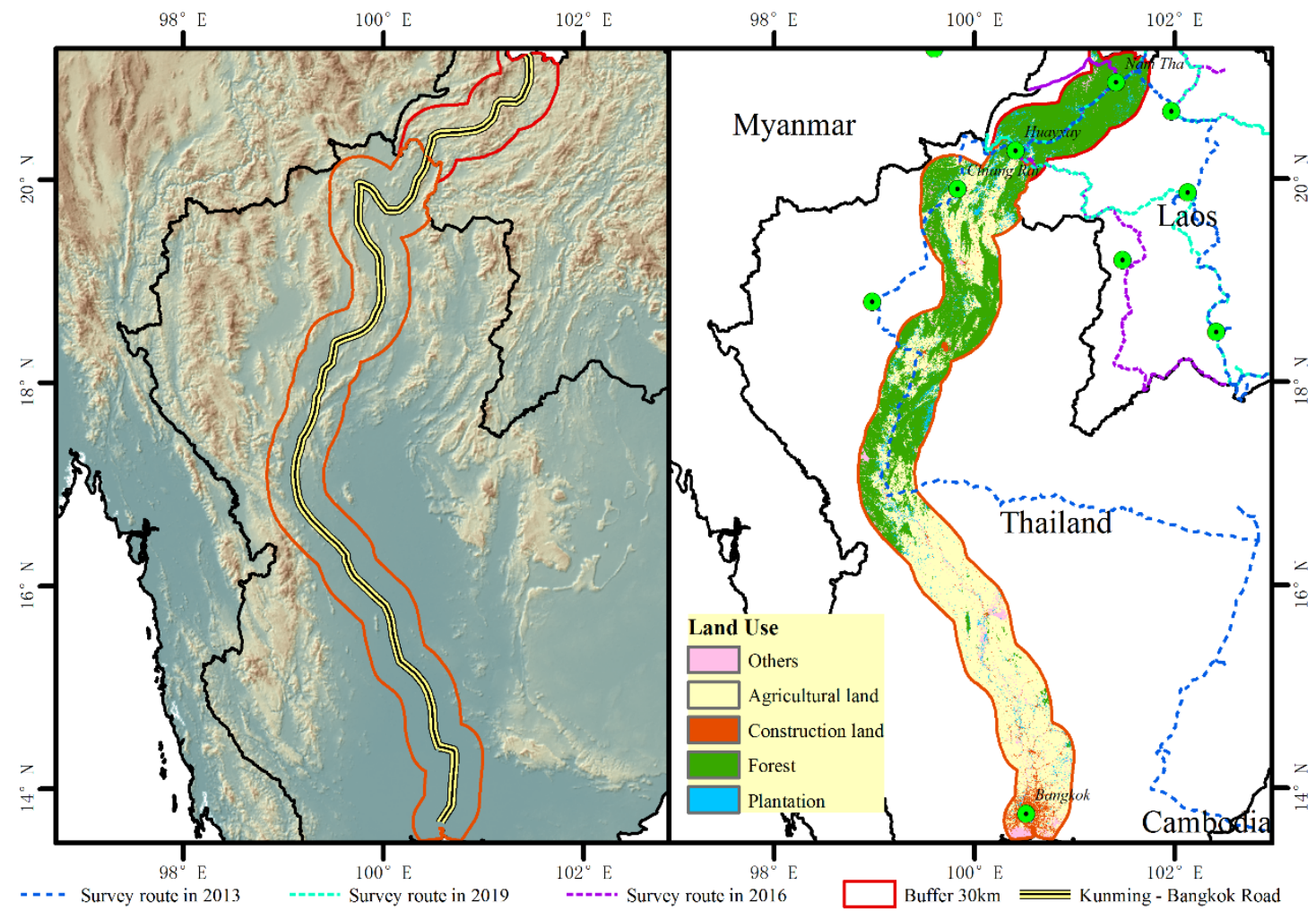

Figure 1. Maps of the $30 \mathrm{~km}$ buffer area of the Kunming-Bangkok Highway and its topography (ASTER GDEM), showing land use in 2018 as well as the results of field surveys in 2013, 2016, and 2019.

Part of the highway in China was built in 2008. Construction on the Laotian section began in 2004. By December 2012, a bridge connecting Huay Xai and Chiang Khong (or The Fourth Thai-Lao Friendship Bridge) had been built to complete the Kunming-Bangkok Highway.

\subsection{Methods and Materials}

\subsubsection{Land Use Data Products and Pre-Processing}

Annual land use data (2004-2018) (the spatial resolution is $30 \mathrm{~m}$ ) were used from the US Agency for International Development's SERVIR Mekong project for the Mekong region, including Laos and Thailand. The aim of this system is to generate data providing high-quality land cover information to serve a variety of needs of regional and national institutions concerning policy, planning, management, and reporting. For more information about the workflow and method used for annual land cover mapping, the interested reader can refer to the study by Saah et al. [22]. They show that the overall accuracy of products of the SERVIR Mekong dataset is $94 \%$ for 18 land cover classes: Aquaculture, barren land, cropland, evergreen broadleaf forests, flooded forests, forests, grassland, mangroves, mining lands, mixed forests, orchards and plantation forests, rice paddies, shrublands, snow and ice, surface water, urban and built-up land, and wetland. Evergreen broadleaf forests, flooded forests, forests, mixed forests, and shrublands were classified as forests. 
The raster products of forests, agricultural land, construction, and land used for plantation were then used to examine the dynamic land use changes along the Kunming-Bangkok Highway by identifying changes in pixel values in ArcGIS 10.x through raster iterators and buffer analysis. It is worth noting that, "plantation" in the paper mainly refers to "orchards and plantation forests", "agricultural land" mainly refers to "cropland", "forest" mainly refers to "evergreen broadleaf forests, flooded forests, forests, mixed forests, and shrublands", and "construction land" mainly refers to "urban and built-up area".

\subsubsection{Buffer Analysis}

To identify the impact of roads on land use changes, we determined the road buffer distance with step lengths of one $(1-10 \mathrm{~km})$ and five $(10-30 \mathrm{~km})$ to form a series of buffer zones. The buffer zones were distributed on both sides of the highway. To consider the differences between the initial dynamics due to relevant factors in the area and the positive use of land driven by roads, the definition of the range of influence of the road needed to be combined with the trend of changes as well as the range of values of the comprehensive positive dynamics before and after road construction. Moreover, it is judged by the high value area or inflection point of the positive comprehensive dynamic index afterwards [23].

\subsubsection{Index of Comprehensive Dynamic Degree}

The comprehensive dynamic degree (or the LC) can reflect the rate of annual change in all land use in a given region:

$$
L C=\frac{\sum_{i} \Delta L U_{i-j}}{\sum_{i} L U_{i}} \times \frac{1}{t} \times 100 \%
$$

$L C$ refers to the comprehensive dynamic degree, $L U_{i}$ is the area of the $i$-th land use type at the beginning of the monitoring period, $\Delta L U_{i-j}$ represents the area in which the $i$-th land use type is converted into the $j$-th land use type during monitoring, and $t$ is the detection period.

\subsubsection{Expansion/Reduction Intensity Index}

The expansion/reduction intensity index (EI or RI) is the main indicator used to characterize the degree or intensity of the effects of highway construction on land use changes. The expansion/reduction intensity index refers to the area of expansion of a spatial unit as a percentage of its total land area during the study period. To compare the strength or speed of expansion of land use in different research periods, the annual average strength of expansion of each spatial unit was calculated. This was the area of each spatial unit used to standardize its annual average rate of expansion. The index of intensity of expansion is as follows:

$$
\beta=\frac{\left(\mathrm{LUA}_{i, t+n}-\mathrm{LUA}_{i, t}\right) / t}{\mathrm{TLA}_{i}} \times 100
$$

$\beta$ is the expansion/reduction intensity index, LUA indicates the land use of a certain type of area, TLA represents the total area of land use, $i$ refers to the study area, and $t$ indicates the study period.

\section{Results}

\subsection{Characteristics of Major Land Use Changes in 2004-2018}

We considered the land use changes only in forests, agricultural land, plantation land, and land for construction since the areas of the other land use types that had changed due to the construction and operation of the highway were minor. During 2004-2018, agricultural land, forests, and land for plantation had prominent characteristics of temporal distribution and periodic differences (Figure S1). The area occupied by forest covered up to $50 \%$ of the total land and was greater than areas of the other types of land use at any 
given time. The second-largest land type was agricultural land, accounting for about $40 \%$ of the total area. Significant changes in the transfer of agricultural land from 2004 to 2018 (Figure 2) (reduced by nearly 2.48\%), with a significant decrease in the areas of forests and arable land (reduced by nearly $3.31 \%$ ). In addition, lands for plantation and construction exhibited a trend of increase. Specifically, the reduction in the area of forested land was the most significant, about 89,900 ha, followed by agricultural land ( 76,900 ha). The area of land used for planting increased significantly, by about 136,200 ha. Although the area of forested land had decreased significantly, this land was not the most prominent type of changes in land use. The area of plantation land underwent the most significant expansion, accounting for $40.74 \%$ of all land use changes, followed by forested land, accounting for $26.91 \%$. A prominent change event was noted when the Kunming-Bangkok Highway was completed in 2013. Therefore, the trends of changes in land use were also different in the periods before and after it began operating.

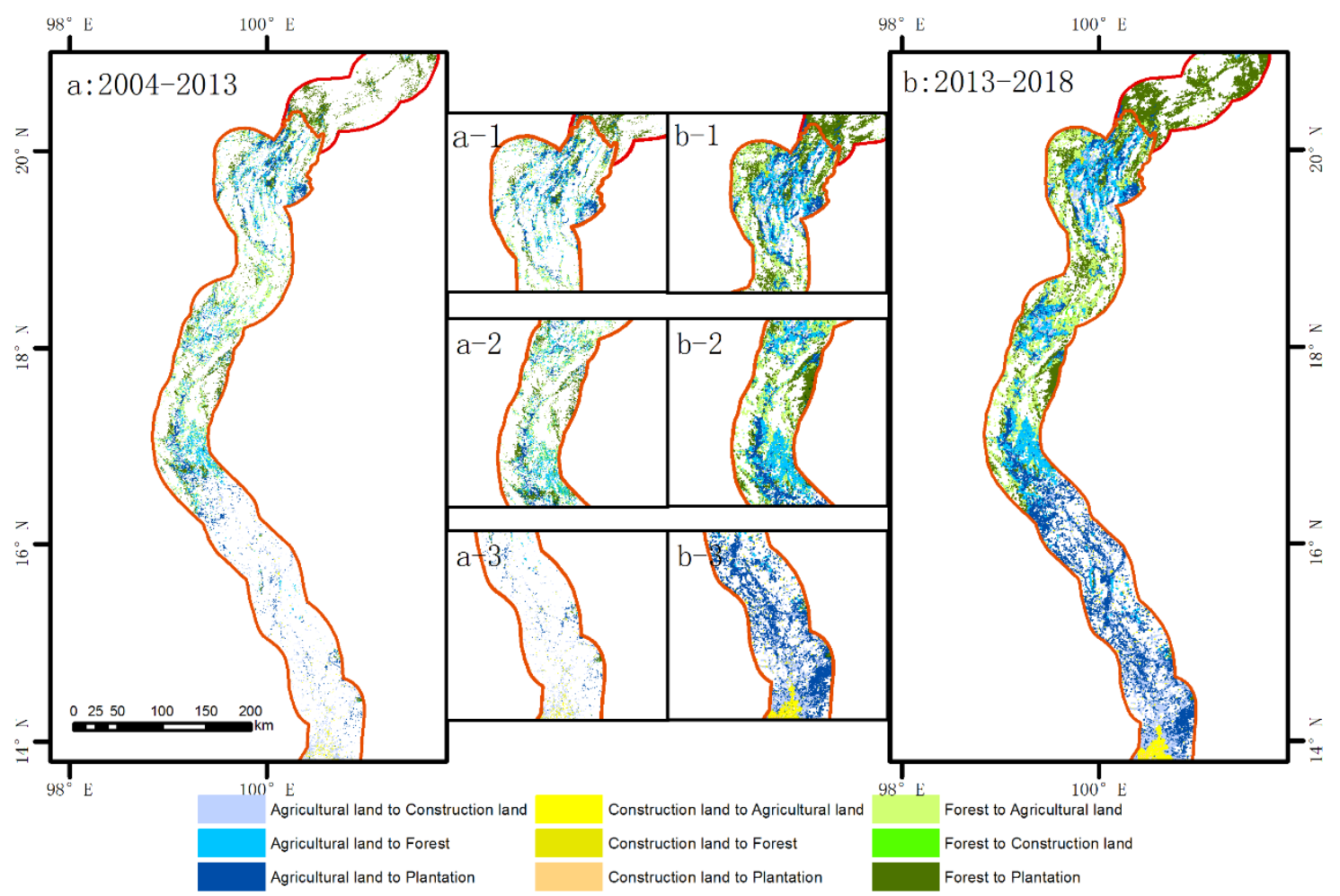

Figure 2. Comparison of spatial changes in major land use types in the $30 \mathrm{~km}$ buffer area in (a) 2004-2013 and (b) $2013-2018$.

The trend of changes in land for plantation was the most significant from 2004 to 2013 , with a relative rate of change of $39.38 \%$, followed by forests $(31.73 \%)$, but exhibited a trend of decrease. Agricultural land also showed a downward trend, with a relative rate of change of $18.15 \%$. The smallest change was noted in the land for construction, which exhibited a trend of increase with a relative rate of change of 5.86\%. From 2013 to 2018, the extent of changes in plantation land was the most significant $(41.89 \%)$, followed by agricultural land, which still exhibited a trend of decrease that was even more severe than that in 2004-2013 (27.07\%). Although construction land still showed a trend of increase, the rate of increase was lower than in 2004-2013 (0.20\%). A comparison of the two periods shows that while their trends of land use types were the same, their relative rates of change were significantly different. Plantation land recorded a substantial trend of increase, but its trend of growth from 2013 to 2018 was more prominent (41.89\% > 39.38\%). Moreover, the relative rate of change of agricultural land in 2013-2018 increased and was higher than that of forests. In 2004-2013, the relative rate of change of agricultural land $(2.48 \%)$ was lower than that of forests (3.31\%). Construction land (3.89\%) also recorded a slight increase, 
but as the highway was opened to traffic, the changes in construction land gradually slowed down.

\subsection{Expansion/Reduction Intensity Index in Buffers of Kunming-Bangkok Highway}

The results show a significant difference in the rate of change as well as intensity across different periods. As shown in Table S1, before the Kunming-Bangkok Highway was opened to traffic (2004-2013), the area of forest land shrank as the distance increased and the intensities of changes were different. When the buffer zone was $1-7 \mathrm{~km}$ from the road, the rate of reduction in forest land continuously decreased, and EI decreased from 0.0886 to 0.0736 . In the buffer zone farther than $7 \mathrm{~km}$ from the road, the rate of reduction in forest land continued to increase, and changes in agricultural land were the same as those of forest land. In the 5 years after the opening of the Kunming-Bangkok Highway (2013-2018), the trends of changes in agricultural land and forest land were the same as before-a trend of decrease with an increasing distance from the road-but with higher intensities than before opening.

The area of plantation reflected a trend of increase in both periods with the same rate of expansion. As the buffer distance increased, their speeds of expansion differed. When the buffer area was $1-4 \mathrm{~km}$, the speed of expansion of planting land continuously decreased. When the buffer zone was $6-10 \mathrm{~km}$, its speed of expansion increased. However, when the buffer zone was farther than $7 \mathrm{~km}$ from the highway, the speed of expansion of forest land showed a decreasing trend. In general, the rate of expansion in 2014-2018 was higher than that in 2003-2013. The change in construction land was the most interesting. When the buffer zone was 3-5 km, the area of construction land increased but the rate of expansion was different between the periods. The rate in 2004-2013 was higher than in 2013-2018. When the buffer distance was 6-11 km, although the intensity of expansion of construction land decreased in both periods, the nature of the trends of change in it was opposite. The area of construction land increased from 2003 to 2014 and decreased from 2014 to 2018. When the buffer zone was greater than $20 \mathrm{~km}$, the area of construction land increased, but its speed of expansion did not change significantly.

\subsection{Comparison of Land Use Transfer and Comprehensive Land Use Dynamics among Buffers}

We combined the EI and RI analyses with the land use transfer matrix of buffer zones at different distances from the highway. Figure 3 shows that when the buffer zone was $1 \mathrm{~km}$, the land use transfer for plantation land was the highest in 2004-2013 (52.06\%). The total area of land use transfer of construction land (0.01\%), agricultural land (53.98\%), and forest land (46.02\%) was 2629.50 ha. In 2013-2018, the land use transfer for agricultural land was the highest $(47.08 \%)$. The total area of land use transfer for construction land $(16.86 \%)$, plantation land $(63.25 \%)$, and forest land $(19.89 \%)$ was 3047.78 ha. With the increase in buffer distance, significant differences were noted between the periods in terms of the type of land use transfer. From 2004 to 2013, as the buffer distance increased, the most significant transfers in land use types were noted in forest land and agricultural land, where the difference between them was small. From 2013-2018, the most significant transfer in the land use type was noted for agricultural land.

In 2004-2013, the overall range of change of the comprehensive land use dynamics was not wide-between $0.24 \%$ and $0.26 \%$ with an average value of $0.24 \%$. In general, the dynamic degree of land use along the route showed a decreasing trend as the distance to the road increased. Moreover, clear points of conflict occurred within $4 \mathrm{~km}$ of the buffer zone (Figure 3). The changes in land use of the 1-4 km buffer zone was quicker than beyond $4 \mathrm{~km}$. The major type of land use transfer was the conversion from planting land to agricultural land and forest land, and the space for construction land was scattered in the surrounding area. When the expressway began operation (2013-2018), the comprehensive land use dynamics were higher than before, and the interval of change was $0.5695-0.6363 \%$ with an average value of $0.6163 \%$. The difference between this and the earlier period was that the most significant change in the buffer zone occurred beyond $10 \mathrm{~km}$. The 
changes were relatively stable when the buffer zone was 1-10 km. The most significant change in the two periods was in the transfer of construction land. Although the distance between the construction land and the buffer zone increased in the two phases, both were mainly transferred to agricultural land. However, the extent of conversion in land use from the construction land to the agricultural land in 2013-2018 was about 10 times that in 2004-2013.
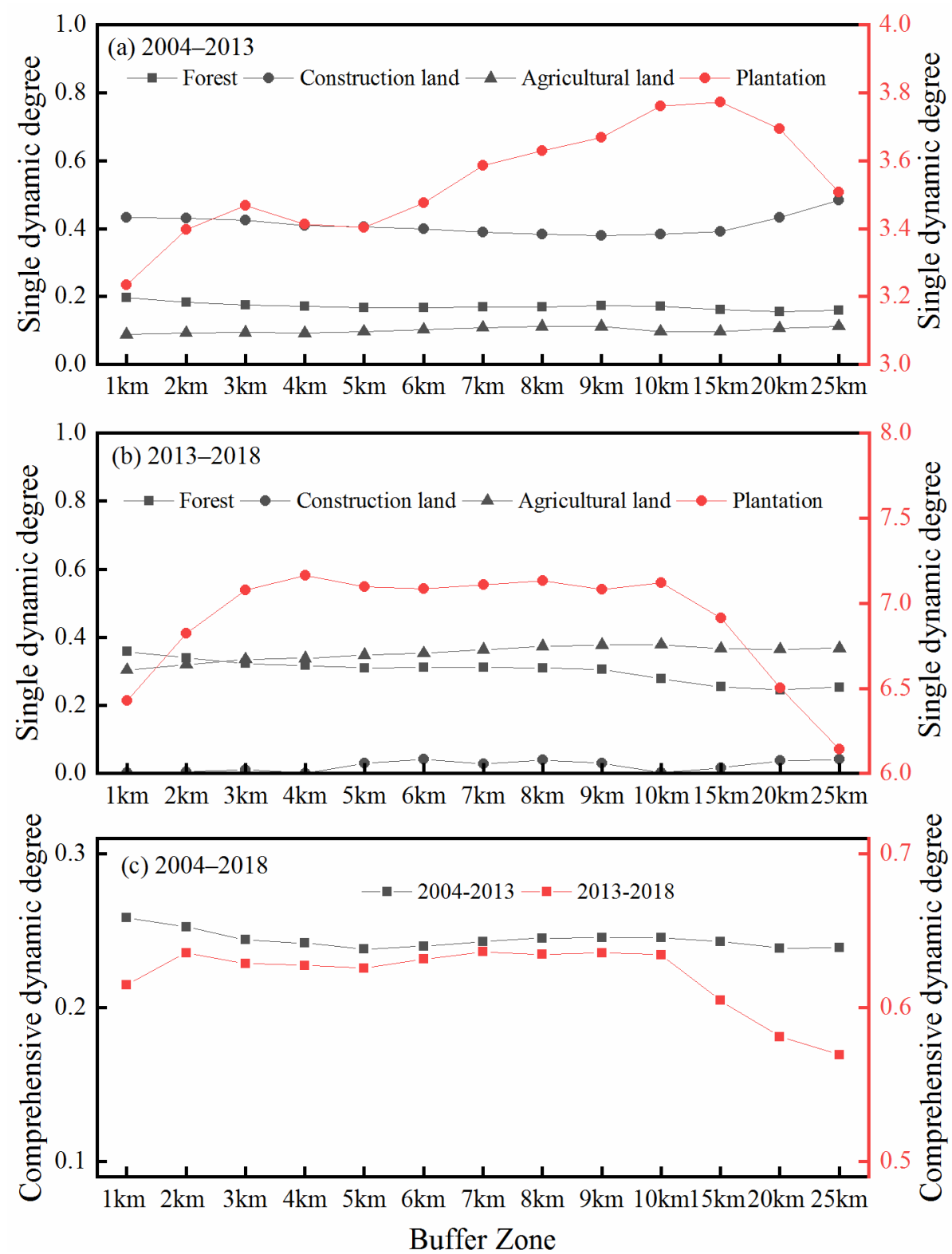

Figure 3. Single/comprehensive degree of land use dynamics in buffers of Kunming-Bangkok Highway. (a) Single land use dynamics from 2004 to 2013; (b) Single land use dynamics from 2013 to 2018; (c) Comprehensive land use dynamics from 2004 to 2018.

When the buffer zone was $1 \mathrm{~km}$, the transfer from the agricultural land was prominent (Figure 4). In 2004-2013, agricultural land was mainly transformed into forest land (1169.66 ha), whereas the areas of land transferred to construction (55.79 ha) and plantation (116.67 ha) were small. However, with the operation of the Kunming-Bangkok Highway, significant changes occurred in terms of the transfer from the agricultural land. Although it was primarily still transformed into forest land, the transfer was mainly concentrated to land for plantation (1927.69 ha). 


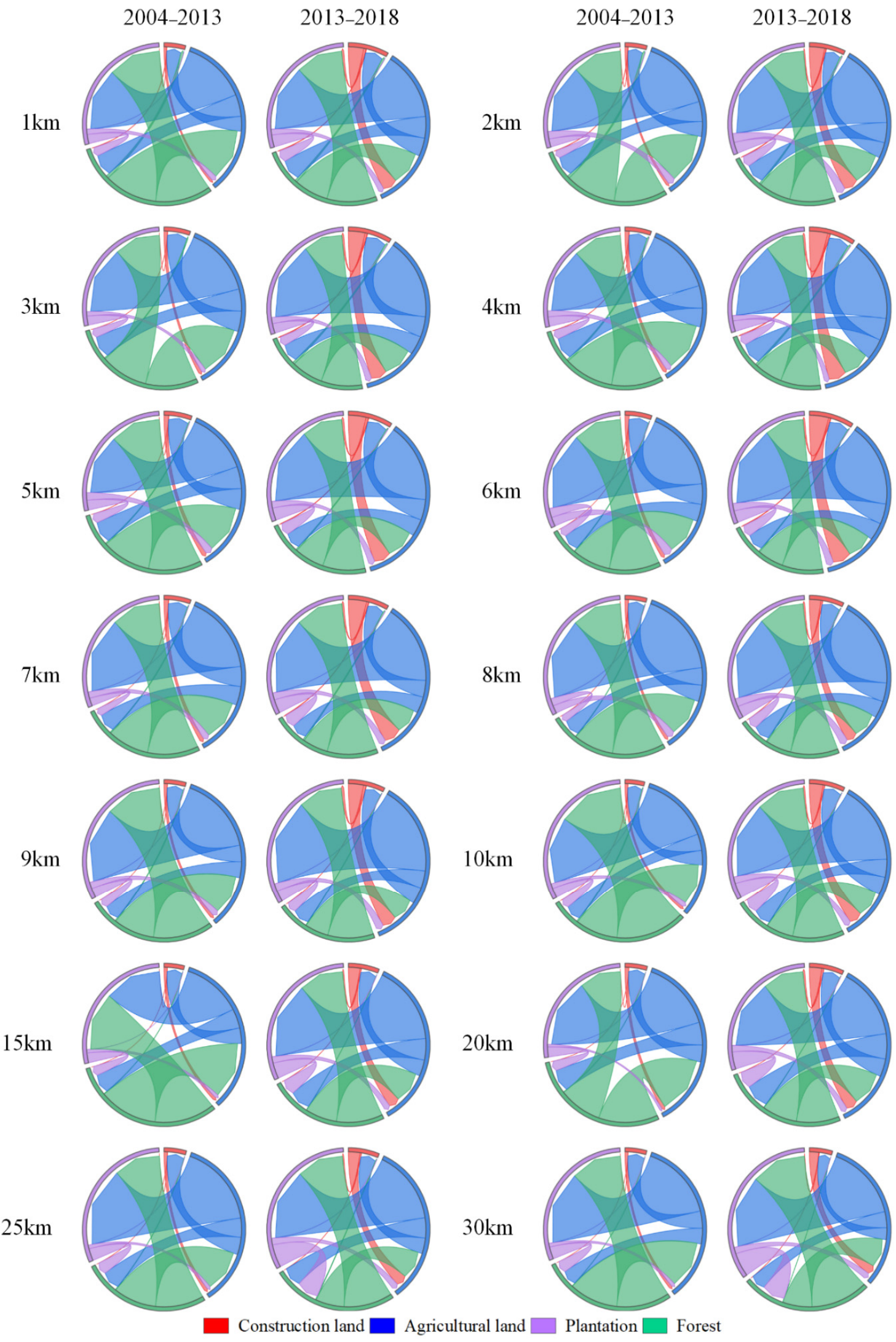

Figure 4. Land use transfer in the buffers of Kunming-Bangkok Highway in 2004-2013 and 2013-2018 (the arrow indicates the direction of transfer, and the width indicates the amount of transfer). 


\section{Discussion}

The causes of changes in land use are complex, and include economic, institutional, political, and demographic factors [24-26]. Road construction is a major contributor to, and consequence of, land use changes. Road construction is an international concern since it poses a wide range of societal and environmental challenges [27-29]. The impact of roads on changes in regional land use have garnered considerable attention [30,31]. While the relationships among roads, accessibility, and land cover are well understood, they have rarely been considered across borders [32]. Cross-border road projects constitute strategic corridors for the growth of commerce among neighboring countries and have changed the infrastructure across land [33]. The fact that these roads pass through national frontiers makes the assessment of the impact of infrastructure especially complicated, since it multiplies the array of national rules on land use [34].

The impact of roads on land use changes can be analyzed from two perspectives. The first is the impact on biodiversity and ecological environment, which can be assessed in terms of the conversion of forest land. Second, the effects of human activities are mainly manifested in the expansion or contraction of construction land, and changes in plantation land and agricultural land. According to the theory of top succession, the transfer of forest land to other land types is the reverse succession of the ecosystem, indicating that it has degraded [35]. The shift from forest land to agricultural land and planting land reflects the pressure of human disturbance on the natural ecosystem. Most of the relevant research has focused on changes in land use types over a short period of time, and continuous, long-term series analyses of the factors influencing these changes. However, how do we assess the impact of an event that leads to sudden and prominent changes in land use? This study used the Kunming-Bangkok Highway as an example of such an event to answer this question.

The buffer analysis can accurately define the range of impact of roads of changes in land use. It has been widely used to study the impact of roads on the ecological environment [36-38]. International standards for road buffers are not suitable for all the areas [39]. The effects of the road network on regional land use change significantly with the distance from the road. Different areas are affected by the natural background as well as the directional influence of social and economic development. Most of the relevant research has shown that the comprehensive land use dynamics of the buffer zone decreases with the increase in the distance from the road [40,41]. The results of this paper on the comprehensive dynamics of land use in the Kunming-Bangkok Highway buffer zone indicate whether it is before the operation of the Kunming-Bangkok Highway or after a period of operation. The dynamic degree of comprehensive changes in land use decreased with the increase in the distance from the highway, which was consistent with the results of most of the past research. However, the impact of the highway on the buffer zone is not the same.

For example, the Qinghai-Tibet Railway has a significant impact on land use changes in a range of $7 \mathrm{~km}$ [42]. The range of impact of the highway from Glomus to Tangela Mountain is 1 3 km [43]. Other studies have found that due to the topography and geomorphology of the area, the threshold of impact is $1 \sim 5 \mathrm{~km}$ around the road [44]. Past research did not conduct a comparative analysis of periods before and after a highway was opened to traffic. Therefore, we analyzed the degree of changes in various types of land use in a $30 \mathrm{~km}$ buffer zone along the Kunming-Bangkok Highway. The results showed that different land use types are inconsistently affected by the highway in the same buffer zone.

In the period (2004-2013) in which the expressway was not yet accessible, the overall dynamics were not prominent, and there was no clear point of conflict. However, the dynamics of land use in the vicinity of the road (within $2 \mathrm{~km}$ ) were slightly higher farther away. The comprehensive dynamic degree did not exceed $0.25 \%$. The major conversion in land use occurred from planting and agricultural land to forest land. When the highway was opened to traffic (2013-2018), the dynamic degree of the buffer zone in the study area was the highest at $2 \mathrm{~km}$ and fluctuated with the increasing distance from the road. Agricultural land and construction land changed between the periods from being scattered 
to forming clusters along the road. This is mainly due to the fact that the road network is the basic framework of urban development, and its spatial structure affects the formation and development of the basic outline of urban space. As the basic functional unit of the city, the utilization of construction land is inevitably affected by the development level of regional roads. The impact is first reflected in the macro-layout of the functions of construction land. Moreover, promoting the continuous increase in the total amount of land use along the line, and objectively forming a land development channel to promote the development of areas along the line, are also the reasons for the increase in construction land. After the operation of the highway, due to the improvement of regional accessibility, the economic production cost is greatly reduced, and the suitable functions of the land along the line are further improved, resulting in the rapid expansion of the construction land area. The east axis is a continuous strip of spatial characteristics. This was a "point axis" pattern, where the distribution of land use changes transitioned from a "dot" to an "axis" pattern. Comprehensive dynamics in the later period of the operation of the highway were higher, indicating that land use changes were more significant after the highway began operation, and tended to ease after reaching a certain level. The expansion of construction land is bound to be supplemented by other types of land. The total loss of cultivated land, forest land, water bodies, and orchards as well as other land types will all flow to the construction land. It shows that in the area along Kunming and Manchuria, other types of land have rapidly shifted to construction land after the operation of the expressway, and the road has become the axis of regional urban expansion.

The dynamics of forest land and agricultural land before the operation of the KunmingBangkok Highway were lower than those of construction land and plantation land. The farmland and plantation land show opposite dynamics. The decline of agricultural land shows that roads have an impact on the suitability of agriculture, affecting its own attributes of agriculture, and then turning it into a more suitable planting industry. The expansion of rubber plantations is an important reason for the increase in plantation [45]. The most prominent dynamic change occurred in the planting land within $4 \mathrm{~km}$ of the buffer zone. As the distance to the buffer zone increased, the dynamics of the plantation decreased first and then increased. When the buffer zone was $15 \mathrm{~km}$ from the road, the dynamics showed a trend of decrease. This was opposite to changes in construction land, the dynamics of which decreased first and then increased with the increase in the distance to the buffer zone. Moreover, this shows that the impact of highway traffic on land use changes was "axial." In the 5 years after the Kunming-Bangkok Highway was officially opened to traffic in 2013, the dynamics of construction land changed slowly. Although it showed a slight increase in dynamics with the increase in the distance to the buffer zone, the area of change in the construction land decreased with the increase in this distance. The dynamics of forest land and agricultural land changed drastically. The dynamics of the planting industry were opposite before and after the opening of the highway. This shows that the operation of the Kunming-Bangkok Highway has had a significant impact on land use changes in the area. Affected by human activities, the spatial variation of land use around the highway is closely related to the transfer in land use types.

\section{Conclusions}

This study used data from the US Agency for International Development's SERVIR Mekong project in the Mekong region, including Laos and Thailand, consisting of 18 land cover classes. We used them to examine dynamic changes in land use along the Kunming-Bangkok Highway by detecting changes in pixel values in ArcGIS 10.x via raster iterators and buffer analysis. The results showed the following: Once the KunmingBangkok Highway was opened to traffic, the dynamics of land use were much higher than before it was opened (the comprehensive dynamic degrees of land use were 0.2445 and 0.6163 , respectively), and the impacts of the highway on land use changes were different. Before the opening, the area of significant impact was within $4 \mathrm{~km}$ of the buffer zone (the comprehensive dynamic degree was 0.2379 ) and was $10 \mathrm{~km}$ after the opening. The 
changes in land use in this buffer zone were drastic (the comprehensive dynamic degree is 0.6343). Moreover, with the increase in the distance to the buffer zone, the higher degree of transfer of land use types in the two periods is plantation (e.g., rubber and orchard), and the direction of transfer is mainly to agricultural land (47.07\% and $52.07 \%)$.

There are several limitations in this study. We mainly considered the impact of a single expressway on changes in land use and did not consider the impact of other roads along the line on the landscape pattern. Analyzing the influence of political and economic factors in the buffer zone on the spatial pattern can also help in understanding the specific reasons for changes in various types of land use. We found that the interaction between the characteristics of the highway and models of spatial development of construction land is still unclear. In the future, it is important to examine the strength of the influence of other factors on the condition of the highway. Researchers should also use more refined data on traffic, land use, and the economic population to conduct a more comprehensive analysis of the degree of impact of highways on changes in land use types.

Supplementary Materials: The following are available online at https:/ / www.mdpi.com/article/ 10.3390/land10090991/s1, Table S1. Expansion/reduction in the intensity index from 2004 to 2013. Figure S1. Major land use types and changes in the $30 \mathrm{~km}$ buffer areas of the Kunming-Bangkok Highway in 2004-2018. Figure S2. Major land use types in the $30 \mathrm{~km}$ buffer areas of the KunmingBangkok Highway in 2004, 2013, and 2018.

Author Contributions: All authors contributed to the work. C.X., Z.F., and F.Z. developed and designed this research. F.Z. performed the data interpretation and analysis and wrote the original draft. C.X. supported the data collection and reviewed the draft. J.H. checked the manuscript for language and helped draw the figures. All authors have read and agreed to the published version of the manuscript.

Funding: This research was funded by the National Natural Science Foundation of China (42001226 and 42130508), and the Strategic Priority Research Program of the Chinese Academy of Sciences (XDA20010203).

Conflicts of Interest: The authors declare that they have no known competing financial interests or personal relationships that could have appeared to influence the work reported in this paper. The authors declare no conflict of interest.

\section{References}

1. Kasraian, D.; Raghav, S.; Miller, E.J. A multi-decade longitudinal analysis of transportation and land use co-evolution in the Greater Toronto-Hamilton Area. J. Transp. Geogr. 2020, 84, 102696. [CrossRef]

2. Knight, R.L.; Trygg, L.L. Evidence of land use impacts of rapid transit systems. Transportation 1977, 6, 231-247. [CrossRef]

3. Demirel, H.; Sertel, E.; Kaya, S.; Zafer Seker, D. Exploring impacts of road transportation on environment: A spatial approach. Desalination 2008, 226, 279-288. [CrossRef]

4. Forman, R.T.T.; Sperling, D.; Bissonette, J.A.; Clevenger, A.P.; Cutshall, C.D.; Dale, V.H.; Fahrig, L.; France, R.; Heanue, K.; Goldman, C.R.; et al. Road Ecology: Science and Solutions; Island Press: Washington, DC, USA, 2003.

5. Roukouni, A.; Basbas, S.; Kokkalis, A. Impact of a metro station to the land use and transport system: The Thessaloniki Metro case. Procedia-Soc. Behav. Sci. 2012, 48, 1155-1163. [CrossRef]

6. Forman R T, T. Estimate of the area affected ecologically by the road system in the United States. Conserv. Biol. 2000, 14, 31-35. [CrossRef]

7. Vermote, L.; Macharis, C.; Hollevoet, J.; Putman, K. Participatory evaluation of regional light rail scenarios: A flemish case on sustainable mobility and land-use. Environ. Sci. Policy 2014, 37, 101-120. [CrossRef]

8. Harris, C.D.; Ullman, E.L. The nature of cities. Ann. Am. Acad. Political Soc. Sci. 2016, 242, 7-17. [CrossRef]

9. He, Y.; Wu, D.; Liu, Y. A review on the impacts of Public Rail Transport on Urban Land Use Change: Citespace-based Quantitative Analysis. Adv. Earth Sci. 2018, 33, 1259-1271.

10. Ullman, E.L. The role of transportation and the bases for interaction. In Man's Role in Changing the Face of the Earth; Thomas, W.L., Jr., Ed.; The University of Chicago Press: Chicago, IL, USA, 1956; pp. 862-880.

11. Baerwald, T.J. Land use change in suburban clusters and corridors. Transp. Res. Rec. 1982, 861, 7-12.

12. Li, R.; Wu, J.; Liu, H.; Gao, Z.; Sun, H.; Ding, R.; Tang, T. Crowded Urban Traffic: Co-evolution among Land Development, Population, Roads and Vehicle Ownership. Nonlinear Dyn. 2019, 95, 2783-2795. [CrossRef]

13. Forman, R.T. Road ecology: A solution for the giant embracing us. Landsc. Ecol. 1998, 13, III-V. [CrossRef]

14. Andrews, A. Fragmentation of habitat by roads and utility corridors: A review. Aust. Zoologist 1990, 26, 130-141. [CrossRef] 
15. Heilman, G.E.; Strittholt, J.R.; Slosser, N.C.; Dellasala, D.A. Forest fragmentation of the conterminous United States: Assessing forest intactness through road density and spatial characteristics. Bioscience 2002, 52, 411-422. [CrossRef]

16. Saunders, S.C.; Mislivets, M.R.; Chen, J.; Cleland, D.T. Effects of roads on landscape structure within nested ecological units of the Northern Great Lakes Region, USA. Biol. Conserv. 2002, 103, 209-225. [CrossRef]

17. Hawbaker, T.J.; Radeloff, V.C. Roads and landscape pattern in Northern Wisconsin based on a comparison of four road data sources. Conserv. Biol. 2004, 18, 1233-1244. [CrossRef]

18. Wang, Z.; Liu, Y.; Wei, J.; Zeng, H. Research on the impact of roads on land use in rapidly urbanized areas. Environ. Sci. Res. 2008, $21,180-185$.

19. Ma, Z.; Li, C.; Zhang, J. Transportation and Land Use Change: Comparison of Intracity Transport Routes in Changchun, China. J. Urban Plan. Dev. 2018, 144, 05018015. [CrossRef]

20. Su, S.; Xiao, R.; Li, D.; Hu, Y. Impacts of transportation routes on landscape diversity: A comparison of different route types and their combined effects. Environ. Manag. 2014, 53, 636-647. [CrossRef] [PubMed]

21. Jin, F.; Wang, C.; Li, X.; Wang, J. China's regional transport dominance:Density, proximity, and accessibility. J. Geogr. Sci. 2010, 20, 295-309. [CrossRef]

22. Saah, D.; Tenneson, K.; Poortinga, A.; Nguyen, Q.; Chishtie, F.; San Aung, K.; Markert, K.N.; Clinton, N.; Anderson, E.R.; Cutter P.; et al. Primitives as building blocks for constructing land cover maps. Int. J. Appl. Earth Obs. Geoinf. 2020, 85, 101979. [CrossRef]

23. Huang, Y.; Li, Y.B.; Ying, H. The Land Use Change and Landscape Pattern Response Driven by YU-YI Expressway (Chongqing Section). J. Nat. Resour. 2015, 30, 1449-1460.

24. Ahmed, N.A.; Mahmood, T.S. Changes in Land Use and Its Impact on the Hierarchy of Roads in Ramadi City. IOP Conf. Ser. Earth Environ. Sci. 2021, 754, 012015. [CrossRef]

25. Zeng, C.; Zhao, Z.; Wen, C.; Yang, J.; Lv, T. Effect of Complex Road Networks on Intensive Land Use in China's Beijing-TianjinHebei Urban Agglomeration. Land 2020, 9, 532. [CrossRef]

26. Man, C.Y.; Shyr, O.F.; Hsu, Y.Y.; Shepherd, S.; Lin, H.L.; Tu, C.H. Tourism, transport, and land use: A dynamic impact assessment for Kaohsiung's Asia New Bay Area. J. Simul. 2020, 14, 304-315. [CrossRef]

27. d'Amour, C.B.; Reitsma, F.; Baiocchi, G.; Barthel, S.; Güneralp, B.; Erb, K.H.; Haberl, H.; Creutzig, F.; Seto, K.C. Future urban land expansion and implications for global croplands. Proc. Natl. Acad. Sci. USA 2017, 114, 8939-8944. [CrossRef] [PubMed]

28. He, C.; Liu, Z.; Tian, J.; Ma, Q. Urban expansion dynamics and natural habitat loss in China: A multiscale landscape perspective. Glob. Chang. Biol. 2014, 20, 2886-2902. [CrossRef]

29. Seto, K.C.; Güneralp, B.; Hutyra, L.R. Global forecasts of urban expansion to 2030 and direct impacts on biodiversity and carbon pools. Proc. Natl. Acad. Sci. USA 2012, 109, 16083-16088. [CrossRef] [PubMed]

30. Zong, Y.; Zhou, S.; Peng, P.; Liu, C.; Guo, R.; Chen, H. Progress in road ecology research. Chin. J. Appl. Ecol. $2003,14,447-452$.

31. Wang, Z.; Zeng, H.; Wei, J. Landscape ecology in road ecology. Chin. J. Ecol. 2007, 26, 1665-1670.

32. Perz, S.G.; Qiu, Y.; Xia, Y.; Southworth, J.; Sun, J.; Marsik, M.; Karla, R.; Veronica, P.; Daniel, R.; Gabriel, A.; et al. Trans-boundary infrastructure and land cover change: Highway paving and community-level deforestation in a tri-national frontier in the Amazon. Land Use Policy 2013, 34, 27-41. [CrossRef]

33. Bourguignon, F.; Pleskovic, B. Rethinking infrastructure for development. In Annual World Bank Conference on Development Economics-2007; World Bank: Washington, DC, USA, 2008.

34. Feder, G.; Feeny, D. Land tenure and property rights: Theory and implications for development policy. World Bank Econ. Rev. 1991, 5, 135-153. [CrossRef]

35. Jimenez, Y.G.; Aráoz, E.; Grau, H.R.; Paolini, L. Linking forest transition, plant invasion and forest succession theories: Socioeconomic drivers and composition of new subtropical andean forests. Landsc. Ecol. 2021, 36, 1161-1176. [CrossRef]

36. Tang, X.; Liu, Y.; Ren, Y.; Ren, Y.; Xiao, X. Land use and ecosystem service value change along expressway. J. China Agric. Univ. 2016, 21, 132-139.

37. Liu, S.; Wen, M.; Cui, B.; Yang, M. Road ecological disturbance based on network characteristics: Taking the Lancang River Basin as an example. Acta Ecol. Sin. 2008, 28, 1672-1680.

38. Li, S.; Xu, Y.; Zhou, Q.; Wang, L. Statistical analysis of the relationship between road network and ecosystem fragmentation in China. Prog. Geogr. 2004, 23, 78-85.

39. Xie, Y.; Gong, J.; Wang, H.; Sun, P.; Qian, D. Comparative study on landscape gradients of different road extension axes in oasis city. Sci. Geogr. Sin. 2013, 33, 1434-1441.

40. Zhu, H.; Li, X.; He, S. Spatio-temporal change of land use in Bohai Rim. Acta Geogr. Sin. 2001, 6, $253-260$.

41. Long, H.L.; Li, X.B. Land use pattern in transect of Yangtse River and its influential factors. Acta Geogr. Sin. 2001, 56, 425-434.

42. Yan, J.; Zhang, Y.; Liu, L. Main effect of plateau traffic on land use and landscape pattern change: Lanzhou to Golmud. Acta Geogr. Sin. 2003, 58, 34-44.

43. Zhang, Y.; Liu, L.; Bai, W.; Yan, J.; Li, S.; Zheng, D. Impact of Qinghai-Xizang highway on land use and landscape pattern change: From Golmud to Tanggulashan pass. Acta Geogr. Sin. 2002, 57, 253-266.

44. Zhu, J.J.; Cui, B.S.; Yao, H.R.; Dong, S.K. Land use change and expansion effects caused by road construction in longitudinal range-gorge region. J. Nat. Resour. 2006, 21, 508-515.

45. Liao, C.; Feng, Z.; Li, P.; Liu, X. The spatiotemporal pattern of slash-and-burn agriculture in the border area between Myanmar, Laos and Thailand. Geogr. Res. 2014, 33, 1529-1541. 